\title{
Influence of tropical cyclones on tropospheric ozone: possible implications
}

\author{
Siddarth Shankar Das ${ }^{1}$, Madineni Venkat Ratnam ${ }^{2}$, Kizhathur Narasimhan Uma ${ }^{1}$, \\ Kandula Venkata Subrahmanyam ${ }^{1}$, Imran Asatar Girach ${ }^{1}$, Amit Kumar Patra ${ }^{2}$, Sundaresan Aneesh ${ }^{1}$, \\ Kuniyil Viswanathan Suneeth ${ }^{1}$, Karanam Kishore Kumar ${ }^{1}$, Amit Parashuram Kesarkar ${ }^{2}$, Sivarajan Sijikumar ${ }^{1}$, and \\ Geetha Ramkumar $^{1}$
}

${ }^{1}$ Space Physics Laboratory, Vikram Sarabhai Space Centre, Trivandrum-695022, India

${ }^{2}$ National Atmospheric Research Laboratory, Gadanki-517112, India

Correspondence to: Siddarth Shankar Das (dassiddhu@yahoo.com)

Received: 9 June 2015 - Published in Atmos. Chem. Phys. Discuss.: 15 July 2015

Revised: 6 April 2016 - Accepted: 7 April 2016 - Published: 19 April 2016

\begin{abstract}
The present study examines the role of tropical cyclones in the enhancement of tropospheric ozone. The most significant and new observation reported is the increase in the upper-tropospheric (10-16 km) ozone by $20-50 \mathrm{ppbv}$, which has extended down to the middle $(6-10 \mathrm{~km})$ and lower troposphere $(<6 \mathrm{~km})$. The descent rate of enhanced ozone layer during the passage of tropical cyclone is $0.8-1 \mathrm{~km} d a y^{-1}$, which is three times that of a clear-sky day (non-convective). Enhancement of surface ozone concentration by $\sim 10 \mathrm{ppbv}$ in the daytime and 10-15 ppbv in the night-time is observed during a cyclone. Potential vorticity, vertical velocity and potential temperature obtained from numerical simulation, reproduces the key feature of the observations. A simulation study indicates the downward transport of stratospheric air into the troposphere. Space-borne observations of relative humidity indicate the presence of sporadic dry air in the upper and middle troposphere over the cyclonic region. These observations quantitatively constitute experimental evidence of redistribution of stratospheric ozone during cyclonic storms.
\end{abstract}

\section{Introduction}

The stratospheric ozone $\left(\mathrm{O}_{3}\right)$ layer, found around $25-30 \mathrm{~km}$ altitude regulates the amount of ultraviolet radiation coming from the Sun to the Earth's surface. Ozone is an important greenhouse gas, which acts as an oxidant in the troposphere and has an important role in climate forcing (Forster et al.,
2007; Pan et al., 2015). One of the major consequences of the tropospheric ozone enhancement is on living organisms, as it acts as a toxic agent among air pollutants (National Research Council, 1991). Increase in the tropospheric ozone is considered to be due to (1) in situ photochemical formation associated with lightning, advection, anthropogenic activities (e.g. Jacobson, 2002, and references therein), and (2) stratospheric flux (Wild, 2007, and reference therein; Škerlak al., 2014). The tropopause, which acts a barrier between the troposphere and the stratosphere, plays a key role in controlling the flow of minor constituents from one layer to other. The increase of the ozone downward flux from the stratosphere to the troposphere not only increases the tropospheric ozone, but also decreases the stratospheric ozone. The ozone presence in the troposphere (intruded from the stratosphere) further reacts with tropospheric water vapour and the tropospheric ozone is destroyed. In principle, the total columnar ozone decreases and thus there will be an enhancement in the penetration of UV radiation to the Earth's surface.

In general, stratospheric-air intrusion into the troposphere is observed over the middle and higher latitudes, which are linked with synoptic scale disturbances (e.g. Stohl et al., 2003). This downward flow is attributed to the dissipation of extra-tropical planetary and gravity waves in the stratosphere (Holton et al., 1995). Stohl et al. (2003) and Bourqui and Trepanier (2010) have reported the continuous downward flows from the stratosphere to the troposphere in a much smaller timescale over the extratropics. In the global ozone budget, $25-50 \%$ of tropospheric ozone sources 
are from middle-latitude stratospheric intrusion (Bourqui and Trepanier, 2010). Appenzeller and Davies (1992) have also discussed that exchange between the stratosphere and the troposphere (both directions) is highly episodic. There is much observational evidence supporting the slow intrusion of stratospheric air into the troposphere during cutoff lows (Vaughan and Price, 1989), high/low-pressure systems (Davies and Schuepbach, 1994), the tropopause folds (Sprenger and Wernli, 2003) and in a rapid episodic manner which is generally triggered by overshooting convections, such as tropical cyclones (Loring Jr. et al., 1996; Baray et al., 1999; Cairo et al., 2008; Das, 2009; Das et al., 2011; Zhan and Wang, 2012; Jiang et al., 2015; Venkat Ratnam et al., 2016). Overshooting convections associated with tropical cyclones can weaken the tropopause stability, which plays a key role in the stratosphere-troposphere exchange. In addition, turbulence caused due to wind shear (Shapiro, 1976) and breaking of gravity waves (Langford et al., 1996) can also be causative mechanisms for the occurrence of stratospheric intrusion. A recent study by Pan et al. (2015) has shown the enhancement of tropospheric ozone associated with the thunderstorm event. Subsidence of stratospheric air is generally observed in the vicinity of the cyclone (Appenzeller and Davies, 1992; Baray et al., 1999; Cairo et al., 2008; Leclair De Bellevue et al., 2006, 2007; Das, 2009; Das et al., 2011; Venkat Ratnam et al., 2016). Slow stratospheric intrusion is reasonably well understood and is a regular phenomenon, whereas rapid intrusion needs to be understood in detail.

The increase in surface ozone is also linked with stratospheric intrusion (e.g. Bourqui and Trepanier, 2010). Earlier studies have also shown, using aircraft measurements, that stratospheric-air intrusion into the troposphere is associated with deep convections by tropopause perturbation (Dickerson et al., 1987; Poulida et al., 1996; Stenchikov et al., 1996; Pan et al., 2015). Stohl et al. (2000) have shown that episodic stratospheric intrusion is associated with severe weather conditions which enhanced the surface ozone concentration.

The bands of the tropical cyclone have intense vertical extended cumulus cloud up to the UTLS region. These bands of cloud are accompanied with updraughts, whereas downdraughts are encountered between these bands. The eyewall region is characterised by local maximum equivalent potential temperature, whereas the minimum is found in the middle to upper troposphere. The eyewall and radius of maximum winds increase with height. The low-pressure core extended to the UTLS region and the horizontal pressure gradient decreased with height (Koteswaram, 1967). Mitra (1996) and Das (2009) reported the weakening of the tropopause during the passage of a tropical cyclone. A detailed study on the dynamical and thermodynamical structure of a tropical cyclone can be found in Hence and Houze Jr. (2012) and the review article on clouds in the tropical cyclone can be found in Houze Jr. (2010). Thus, the tropical cyclones have an influence on the stratosphere-troposphere exchange process which causes air mass and energy transports in the tro-
Table 1. Details of ozonesonde launched from Trivandrum including the historical data for control day analysis.

\begin{tabular}{lr}
\hline Description & Date \\
\hline Cyclone Nilam & 30 October 2012 \\
& 31 October 2012 \\
2 November 2012 \\
5 November 2012 \\
6 November 2012 \\
7 November 2012 \\
\hline Cyclone Phailin & 11 October 2013 \\
& 12 October 2013 \\
13 October 2013 \\
14 October 2013 \\
15 October 2013 \\
\hline 24 October 1995 \\
25 October 1995 \\
7 October 1998 \\
21 October 1998 \\
4 October 2000 \\
4 October 2002 \\
1 October 2003 \\
15 October 2003 \\
30 October 2003 \\
27 October 2004 \\
28 September 2005 \\
25 October 2006 \\
7 October 2009 \\
12 October 2011 \\
13 October 2011 \\
14 October 2011 \\
19 October 2011 \\
27 October 2011 \\
3 October 2012 \\
14 October 2012 \\
28 October 2013 \\
29 October 2013 \\
\hline
\end{tabular}

posphere and redistribution of stratospheric ozone (e.g. Jiang et al., 2015). A complete review on the effect of the tropical cyclones on the upper troposphere and lower stratosphere can be found in Cairo et al. (2008). In spite of many observational and modelling studies, the exchange of air mass from the stratosphere to the lower troposphere in a short timescale, associated with tropical cyclones, is still unclear and further studies are needed. The present study addresses the influence of the tropical cyclones quantitatively on the enhancement of tropospheric ozone by the stratospheric intrusion.

\section{Campaign details and the data analysis}

An intense campaign, named Troposphere-Stratosphere Exchange-Cyclone (TSE-C) under the Climate and Weather of the Sun Earth System (CAWSES) India phase II pro- 
gramme (Pallamraju et al., 2014), was conducted during two cyclone events. Under this campaign, a series of ozonesondes were launched from Trivandrum $\left(8.5^{\circ} \mathrm{N}, 76.5^{\circ} \mathrm{E}\right)$ during the intense period of cyclonic storm Nilam from 30 October to 7 November 2012 and a very severe cyclonic storm Phailin from 11 to 15 October 2013. The ozonesondes used are made by EN-SCI (USA), which were integrated with the GPSbased radiosondes (i-Met). These standard ozonesonde are made up of the Electrochemical Concentration Cell (ECC) (Komhyr et al., 1995). The uncertainty in the ozone measurements is $5-10 \%$. Table 1 also provides the details of ozonesonde measurements conducted during the passage of these cyclonic storms. Ozonesonde data was obtained at a fixed height resolution by down sampling at $100 \mathrm{~m}$ height resolution by the linear interpolation method. The India Meteorological Department (IMD) also launches ozonesondes every fortnight. The background profiles (non-convective day for at least three days) is constructed by averaging the ozonesonde data ( 23 profiles) obtained from the IMD, combined with our observations from 1995 to 2013 for the month October over Trivandrum. The IMD ozonesonde used a Brewer-Mast electrochemical sonde (bubbler) developed in the Ozone Research Laboratory of the IMD. These IMD ozonesondes were compared with ECC sondes and underestimations of $5-10 \%$ were found in the troposphere (Kerr et al., 1994; Deshler et al., 2008), which is about $<2$ ppbv of the observed mean value. Detailed system descriptions of the IMD ozonesonde can be found elsewhere (Sreedharan, 1968; Alexander and Chatterjee, 1980). There is no ozonesonde launch by IMD in this campaign. The measurements of nearsurface ozone are carried out using the online UV photometric ozone analyser (Model AC32M) from Environment S.A, France. This ozone analyser works on the principle of UV absorption of ozone at the wavelength $253.7 \mathrm{~nm}$. The instrument has a lower detection limit of $1 \mathrm{ppbv}$ and $1 \%$ linearity. The data has a sample interval of $5 \mathrm{~min}$.

The SAPHIR (Sondeur Atmosphérique du Profil d'Humidité Intertropicale par Radiométrie) on board the Megha-Tropiques satellite is a multichannel passive microwave humidity sounder, measuring brightness temperatures in six channels located close to the $183.31 \mathrm{GHz}$ water vapour absorption line $( \pm 0.15, \pm 1.20, \pm 2.80, \pm 4.30$, \pm 6.60 and $\pm 11.0 \mathrm{GHz}$ ). These channels allow for retrieving the integrated relative humidity in the ranges of 1000-850, $850-700,700-550,550-400,400-250$ and $250-100 \mathrm{hPa}$. The radiometer has a cross-track scan of $\pm 43^{\circ}$, providing a swath of $1705 \mathrm{~km}$ and a $10 \mathrm{~km}$ resolution at nadir. This data is also used for the qualitative analysis of the stratospheric air. A detailed instrumentation can be found in Raju (2013) and retrieval algorithm in Gohil et al. (2012) and Mathur et al. (2013). Venkat Ratnam et al. (2013) and Subrahmanyam and Kumar (2013) have validated relative humidity data obtained from SAPHIR with other satellite and radiosonde observations.
Apart from the ozonesonde observations, a high-resolution numerical simulation using the Advanced Research Weather Research and Forecast (WRF-ARW) model version 3.6 has also been carried out for both cyclones. The model domain has been configured with two nested domains of 60 and $20 \mathrm{~km}$ horizontal resolution, and covers an area extending from $1^{\circ} \mathrm{S}$ to $25^{\circ} \mathrm{N}$ and 60 to $100^{\circ} \mathrm{E}$. The innermost domain has been used for the present study. The initial and lateral boundary conditions have been taken from the ERA-Interim reanalysis on $0.75^{\circ} \times 0.75^{\circ}$ continuously at every $6 \mathrm{~h}$. The present simulation was carried out with the model physics options: (i) New Simplified ArakawaSchubert (NSAS) (Han and Pan, 2011), (ii) Yonsei University (YSU) boundary-layer scheme (Hong et al., 2006), (iii) rapid radiative transfer model (RRTM) long-wave radiation scheme (Mlawer et al., 1997), (iv) WRF single-moment (WSM) 5-class microphysics scheme (Hong et al., 2004) and (v) National Oceanic and Atmospheric Administration (NOAA) land-surface scheme (Smirnova et al., 2000).

\section{Meteorological background}

The present experiments were conducted during the passage of the (1) cyclonic storm Nilam from 28 October to 1 November 2012 and (2) very severe cyclonic storm Phailin from 4 to 14 October 2013 over the Bay of Bengal (BOB). The track of each tropical cyclone and outgoing long-wave radiation (OLR) images (date- and timestamped) are shown in Fig 1a and b respectively. The detailed bulletin can be found in www.imd.gov.in. During these campaigns, several ozonesondes were launched from Trivandrum whenever the intensity of cyclones was at maximum and the path/eye was close to the launching site. The details of each of the tropical cyclones used for present analysis areas are provided in the following sections.

\subsection{Case-1 (Nilam)}

A depression formed over the south-east of BOB $\left(\sim 9.5^{\circ} \mathrm{N}\right.$, $\left.86.0^{\circ} \mathrm{E}\right)$ at $11: 30 \mathrm{IST}(\mathrm{IST}=\mathrm{UT}+5.5 \mathrm{~h})$ of 28 October 2012. It moved westwards and intensified into a deep depression on the morning of 29 October 2012 over south-west BOB, about $\sim 550 \mathrm{~km}$ south-south-east of Chennai. It continued to move westwards and intensified into a cyclonic storm, Nilam, in the morning of 30 October 2012 over south-west BOB. Then it moved north-north-west, crossed the north Tamil Nadu coast near Mahabalipuram $\left(12.6^{\circ} \mathrm{N}, 80.2^{\circ} \mathrm{E}\right)$, south of Chennai in the evening hours of 31 October 2012. After the landfall, the cyclonic storm Nilam moved west-north-west and weakened gradually into a deep depression and then into a depression in the morning hours of 1 November 2012. 

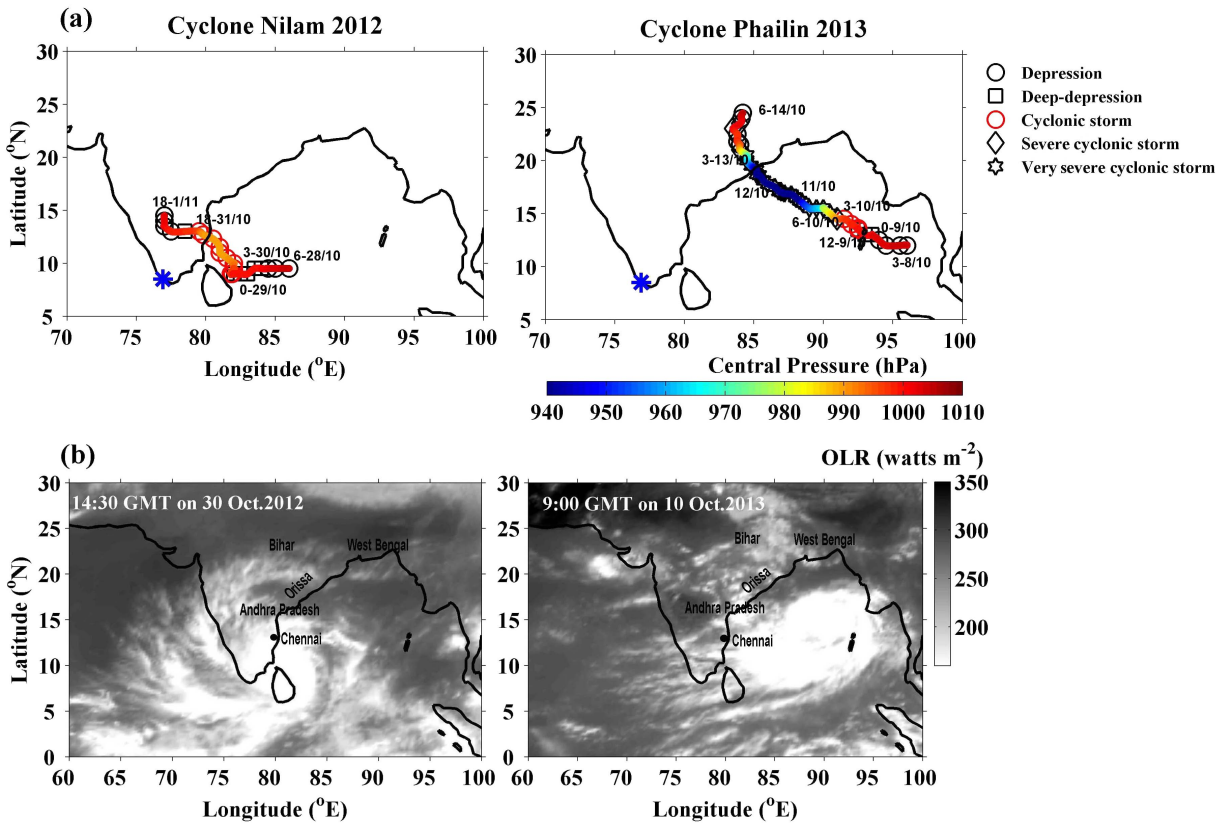

Figure 1. (a) Track of cyclones Nilam and Phailin (top panels) and (b) its outgoing long-wave radiation (OLR) wave radiation at 14:30 GMT on 30 October 2012 (Nilam) and 09:00 GMT on 10 October 2013 (Phailin). In each panel, date and time are mentioned along the track. In the first panel, 18-1/11 indicates 18:00 GMT of 1 November 2012 and similarly followed for others. The blue star in (a) indicates the ozonesonde launching site Trivandrum.

\subsection{Case-2 (Phailin)}

A low-pressure system was formed over Tenasserim coast $\left(\sim 12^{\circ} \mathrm{N}, 96^{\circ} \mathrm{E}\right)$, on the early morning of 6 October 2013 . It intensified into a depression over the same region on 8 October and then moved towards the west-north-westwards. It further intensified into a deep depression in the early morning of 9 October 2013 and then into a cyclonic storm, Phailin in the evening hours. Moving north-westwards, it finally converted into a severe cyclonic storm in the morning hours of 10 October 2013 over east-central BOB. The very severe cyclonic storm continued to move north-westwards and crossed Andhra Pradesh and the Orissa coast near Gopalpur $\left(19.2^{\circ} \mathrm{N}, 84.9^{\circ} \mathrm{E}\right)$ in the late evening of 12 October 2013. It further continued to move north-north-westwards after the landfall for some time, then northward and finally northnorth-eastwards up to south-west Bihar. The system weakened gradually into a cyclonic storm from 13 October 2013 and finally the intensity decreased to a low-pressure system on 14 October 2013.

\section{Results and discussion}

Figure $2 \mathrm{a}-\mathrm{b}$ show the profiles of ozone mixing ratio (OMR) and relative humidity (RH) from ozonesonde measurements during the passage of the tropical cyclones Nilam (top panels) and Phailin (bottom panels). The background ozone profile is obtained by averaging individual profiles ( 23 pro- files) over Trivandrum in October from 1995 to 2013 and is shown by dotted lines in Fig. 2. During the passage of Nilam on 30 October 2012, enhancement in tropospheric ozone (marked by horizontal arrows) from the background by $40-50 \mathrm{ppbv}$ was observed in the height region between 8 and $9 \mathrm{~km}(\sim 1 \mathrm{~km}$ width$)$, and 11 and $14 \mathrm{~km}(\sim 3 \mathrm{~km}$ width $)$. These enhancements persisted until 31 October 2012, but were observed between 6 and $7 \mathrm{~km}$. However, the enhancement of about $\sim 40 \mathrm{ppbv}$ was still observed on 2 November 2012 but the height region decreased to 5-6 km. After two days, we again had observations from 5 to 7 November 2012. The height of enhanced ozone layer in the troposphere reduced to $\sim 4 \mathrm{~km}(40 \mathrm{ppbv}), \sim 3 \mathrm{~km}(30 \mathrm{ppbv})$ and $\sim 1.5 \mathrm{~km}(20 \mathrm{ppbv})$ on 5, 6 and 7 November 2012 respectively. The present observation reveals that the downward propagation of the enhanced upper-tropospheric ozone layer into the lower troposphere occurs in an episodic manner. The descent rate of the ozone-rich layer from the upper troposphere to the boundary layer during Nilam is estimated to be $\sim 875 \mathrm{mday}^{-1}$. It is also noted that the corresponding RH profiles during Nilam did not decrease with increasing ozone mixing ratio except on 2 November 2012. A significant sudden decrease in RH is observed on 2 November 2012 at $\sim 6 \mathrm{~km}$, where the maximum enhancement ( $\sim 70 \mathrm{ppbv})$ of the tropospheric ozone layer is observed. This indicates the presence of accumulated dry air at $6 \mathrm{~km}$. As the stratospheric air is dry and ozone rich, there may be a possibility that on 

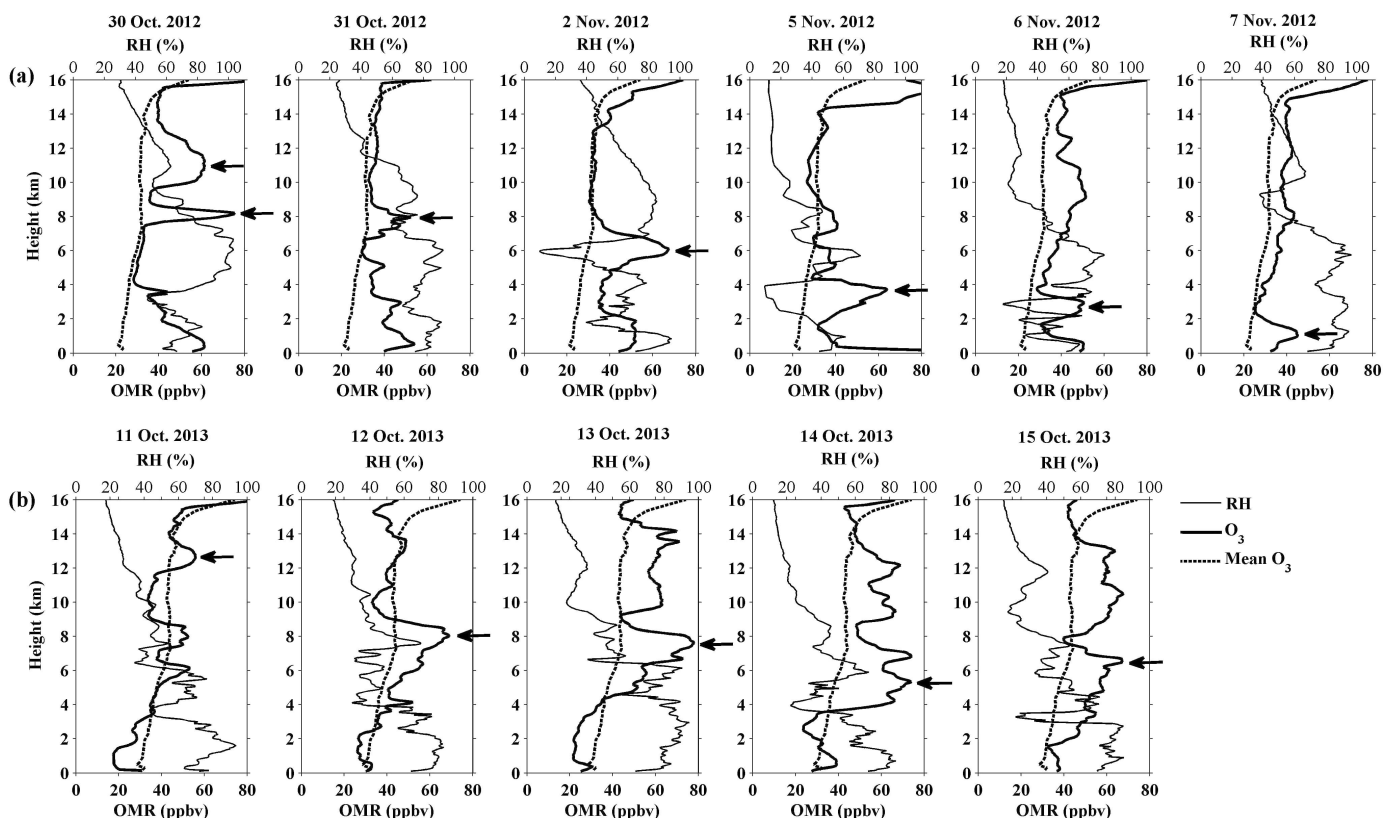

Figure 2. (a) Profiles of ozone mixing ratio (OMR) (dark black line) and relative humidity (grey line) for individual days during the passage of tropical cyclones (a) Nilam and (b) Phailin. The mean ozone mixing ratio profile for non-convective days (as control days) is shown with a dotted line. The mean profile is obtained by averaging ozone data over Trivandrum for the month of October from 1995 to 2013 . Horizontal arrows indicate the height of the enhanced ozone.

2 November 2012 the accumulated dry ozone-rich air at $6 \mathrm{~km}$ may be of stratospheric origin.

A similar phenomenon is also observed during the passage of Phailin. Intrusion from $\sim 14$ to $6 \mathrm{~km}$ (marked by horizontal arrows) is clearly observed in the ozone profiles from 11 to 15 October 2013. During Phailin, tropospheric ozone increases by $20-30 \mathrm{ppbv}$ and the width of the enhanced ozone layer is larger than that observed during Nilam. During Phailin, the descent rate of enhanced ozone layer from the upper troposphere to the boundary layer is estimated to be $\sim 1000 \mathrm{~m} \mathrm{day}^{-1}$. The descent rate in the tropical non-convective region, under the assumption of no vertical winds, may be inferred from the radiative heating rate in the tropical clear-sky regions. Gettelman et al. (2004) estimated tropical clear-sky radiative heating rates by using ozone and water-vapour sounding data together with the radiative transfer models and found -1 to $-2 \mathrm{~K} \mathrm{day}^{-1}$ in the troposphere. If the temperature lapse rate is $6-10 \mathrm{~K} \mathrm{~km}^{-1}$ in the upper troposphere, the descent rate is estimated to be $0.1-0.3 \mathrm{~km} \mathrm{day}^{-1}$. In the present observations, a $0.8-1 \mathrm{~km} \mathrm{day}^{-1}$ descent rate is estimated during the passage of tropical cyclones, which is three times that of clear-sky (non-convective)days with radiative subsidence. This may indicate that downward flow in association with the tropical cyclones (in their outer regions) enhanced the transport of ozone from the stratosphere to the lower troposphere.

As discussed in the introductory section, significant perturbation in the tropopause due to deep convection will
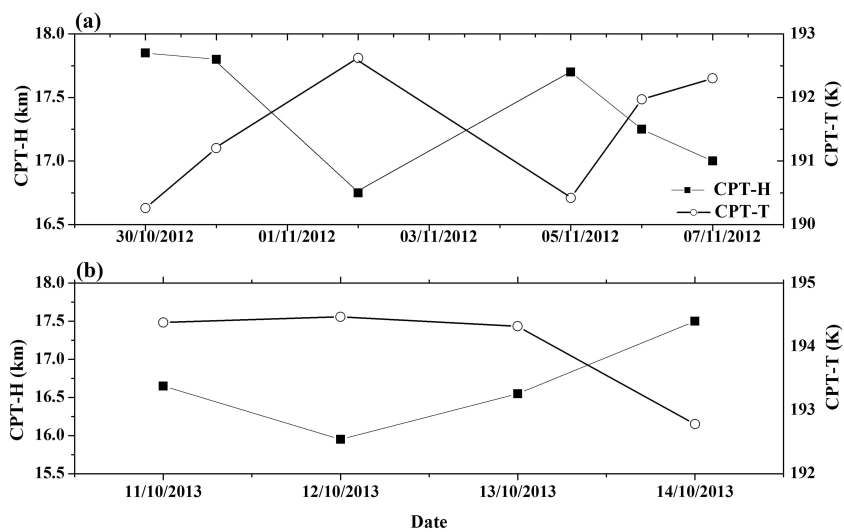

Figure 3. Variation of cold-point tropopause height (CPT-H) and cold-point tropopause temperature (CPT-T) derived from temperature measurement by ozonesonde launched during the passage of tropical cyclones (a) Nilam and (b) Phailin over Trivandrum.

lead to the transport of ozone-rich stratospheric air into the troposphere. Figure 3 shows variation in the cold-point tropopause height (CPT-H) and cold-point tropopause temperature (CPT-T) derived from radiosonde measurements during (a) Nilam and (b) Phailin over Trivandrum. Significant perturbation in the tropopause height and the temperature are observed for both the cyclone cases. The climatological mean tropopause height and temperature over southern India (peninsular) are observed to be $\sim 16.5 \mathrm{~km}$ and $\sim 191 \mathrm{~K}$ 


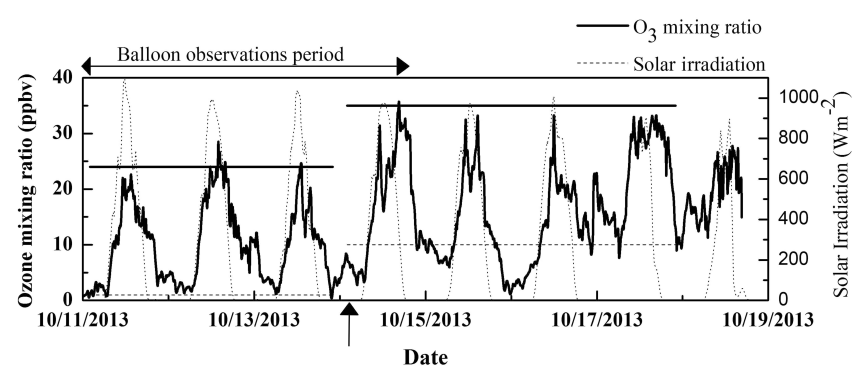

Figure 4. Time series of surface ozone mixing ratio (thick line) along with solar radiation (dotted line) from 00:00 IST on 11 October 2013 to 23:55 IST on 19 October 2013. Solid and dotted horizontal lines indicate the mean maximum and minimum surface ozone. The vertical arrows indicate the nocturnal enhancement of surface ozone. The data is collected with $5 \mathrm{~min}$ resolution.

(Sunilkumar et al., 2013). The CPT-H gradually decreased from $17.8 \mathrm{~km}$ on 30 October to $16.7 \mathrm{~km}$ on 2 November 2012 for Nilam. Afterwards, the CPT-H gradually increased and reached $17.5 \mathrm{~km}$. Similarly for Phailin, the CPT-H decreased from $16.5 \mathrm{~km}$ on 11 October 2013 to $15.8 \mathrm{~km}$ on $12 \mathrm{Oc}$ tober 2013 and then gradually increased. The height above the tropopause (i.e. stratosphere) is in radiative equilibrium, whereas the height below the tropopause (i.e. troposphere) is in radiative-convective equilibrium.

In addition to the profiling of ozone, we have the surface measurement of ozone and solar flux during the Phailin. Figure 4 shows the time series of near-surface ozone mixing ratio along with solar irradiation from 11 to 19 October 2013. As expected, clear diurnal variability is observed in the time series of surface ozone. In general, there are three main mechanisms for the production of ozone in the atmospheric boundary layer: (1) photochemical reaction via $\mathrm{NO}_{x}$ and $\mathrm{CO}$ channel, (2) biomass/fossils fuel burning and (3) lightning. However, David and Nair (2011) have shown the diurnal pattern of surface ozone observed over Trivandrum is due to the mesoscale circulation, i.e. local sea and land breeze and the availability of $\mathrm{NO}_{x}$. From 11 to 14 October the maximum and minimum average peak of surface ozone are observed to be 24 and $1 \mathrm{ppbv}$, whereas from 14 to 18 October 2013, the maximum and minimum are observed to be 35 and $10 \mathrm{ppbv}$. Even though there was no solar radiation in the evening hours, there are enhancements in surface ozone concentration (indicated by vertical arrows) on 1415, 16-17, 18-19 October 2013. The upper and lower averages are indicated by horizontal solid and dash lines respectively. The ozone profiles obtained from ozonesonde measurements also show that enhanced ozone layer propagates downward from the upper troposphere during 11-15 October 2013. There is a possibility that the enhanced tropospheric ozone can further propagate downwards to the near surface in the presence of downdraughts. The enhancement in the surface ozone, even after the cut-off in solar radiation, can be linked to the downward flow of upper-tropospheric ozone in the presence of downdraughts. Time series of solar irradiation show that there was not much change in the radiation among the days 11-13 and 14-17 October 2013. This indicates that the observed enhancement in the surface ozone is not due to changes in sunlight. Over the observation site, land breeze prevails during night-time. The change in night-time ozone depends on the precursor gas (e.g. NO) concentration in land breeze, which has a dependency on local precursor gas emission/human activity. Due to the cyclonic condition over Trivandrum, considerable change in human activity during 11-17 October 2013 would not have happened and biomass burning may not have been possible due to associated rainfall. The day-to-day variability of surface ozone over Trivandrum is $\sim 9.5 \mathrm{ppbv}$ ( $1 \sigma$ standard deviation). The observed enhancement in surface ozone is found to be $\sim 10 \mathrm{ppbv}$ in the daytime and $10-15 \mathrm{ppbv}$ in the nighttime. In a recent study by Jiang et al. (2015), an increase of surface ozone by $21-42 \mathrm{ppbv}$ and surface nocturnal surface ozone levels exceeding $70 \mathrm{ppbv}$ is observed in the region $\mathrm{Xi}$ amen and Quanzhou over the south-eastern coast of China before the Typhoon Hagibis landing. However, there are possible of an influence of lightening associated with cyclone and thus, other possibilities of this surface ozone cannot be fully ruled out. A planned experiment by setting up various ground-based instruments is required to rule out the enhancement of surface ozone.

Furthermore, to support the present observations of stratospheric intrusion into the troposphere and nearer to the surface, a dynamical analysis is carried out using WRF-ARW simulations. Das et al. (2011) and Pan et al. (2015) have shown the ability of WRF simulations during a tropical cyclone. Figure 5 shows the height-time cross section of (a) vertical velocity along with potential vorticity (magenta line) and potential temperature (black line) contours, and (b) relative humidity along with equivalent potential temperature (black line) and zonal wind (grey line) for Nilam (left panels) and Phailin (right panels) over Trivandrum using WRF simulations. Figure 5a shows the presence of strong updraughts (red) and downdraughts (blue) marked with rectangular boxes in the UTLS regions. Enhanced potential vorticity of $0.5-1.5 \mathrm{PVU}$ is also observed vertically down from the stratosphere to the troposphere overlapping the downdraught regions. The potential temperature contours indicate (Fig. 5a) the presence of reduced stability during 29-31 October 2012 (Nilam) and 9-11 October 2013 (Phailin).

Height-time cross section of relative humidity shown in Fig. $5 \mathrm{~b}$ indicates the presence of dry air from $4 \mathrm{~km}$ to the tropopause level. The equivalent potential temperature contours in Fig. $5 \mathrm{~b}$ indicate that from the surface to $\sim 8 \mathrm{~km}$, the atmosphere is highly unstable and favourable conditions for the convection took place during 29-31 October 2012 (Nilam) and 9-11 October 2013 (Phailin). During the same periods, from $10 \mathrm{~km}$ to the tropopause level, the vertical motion is suppressed and the atmosphere is found to be statically stable compared to the unsaturated atmosphere. The present 

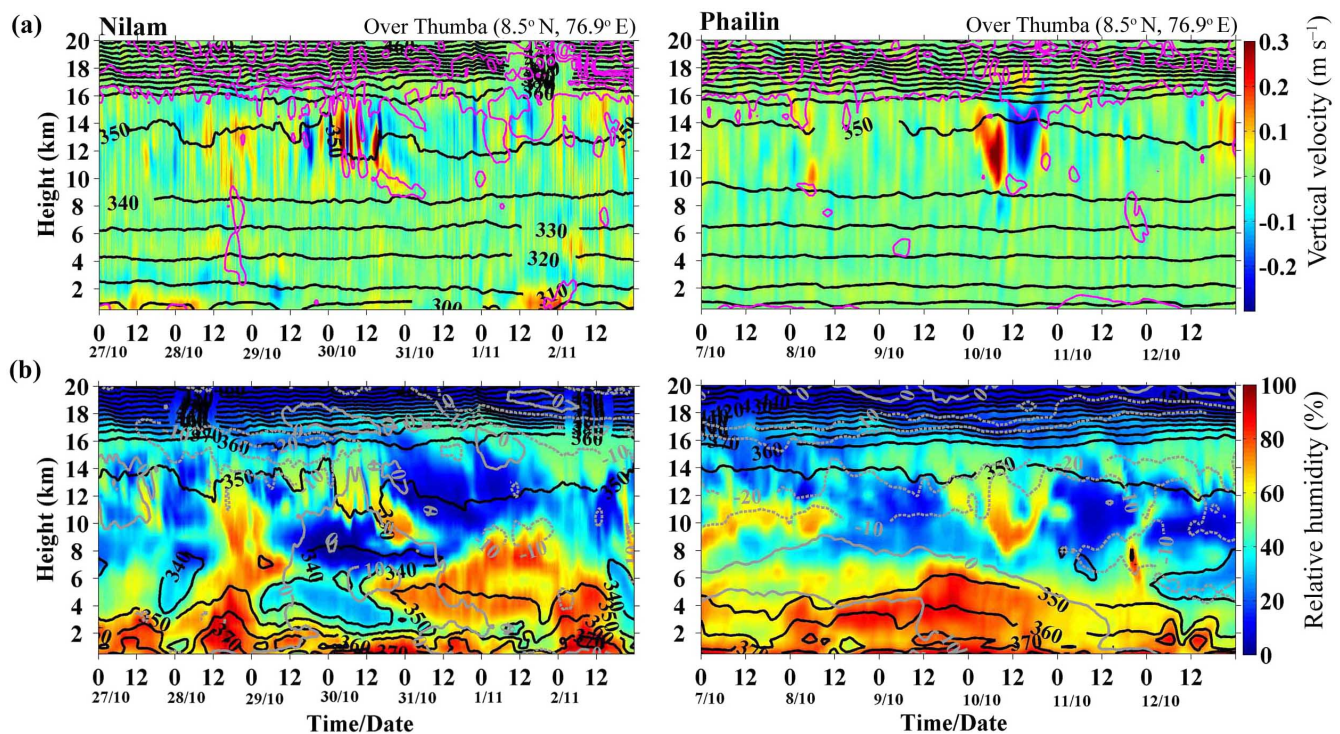

Figure 5. Height-time cross section of (a) vertical velocity along with potential vorticity (magenta line) and potential temperature (black line) contours, and (b) relative humidity along with equivalent potential temperature (black line) and zonal wind (grey line) for Nilam (left panels) over Trivandrum $\left(8.5^{\circ} \mathrm{N}, 76.9^{\circ} \mathrm{E}\right)$ from 27 October to 2 November 2012 and Phailin (right panels) from 7 to 12 October 2013. Rectangular boxes indicate the presence of strong updraughts and downdraughts and the dry air between stratosphere and troposphere. The above parameters are obtained from the WRF simulation.
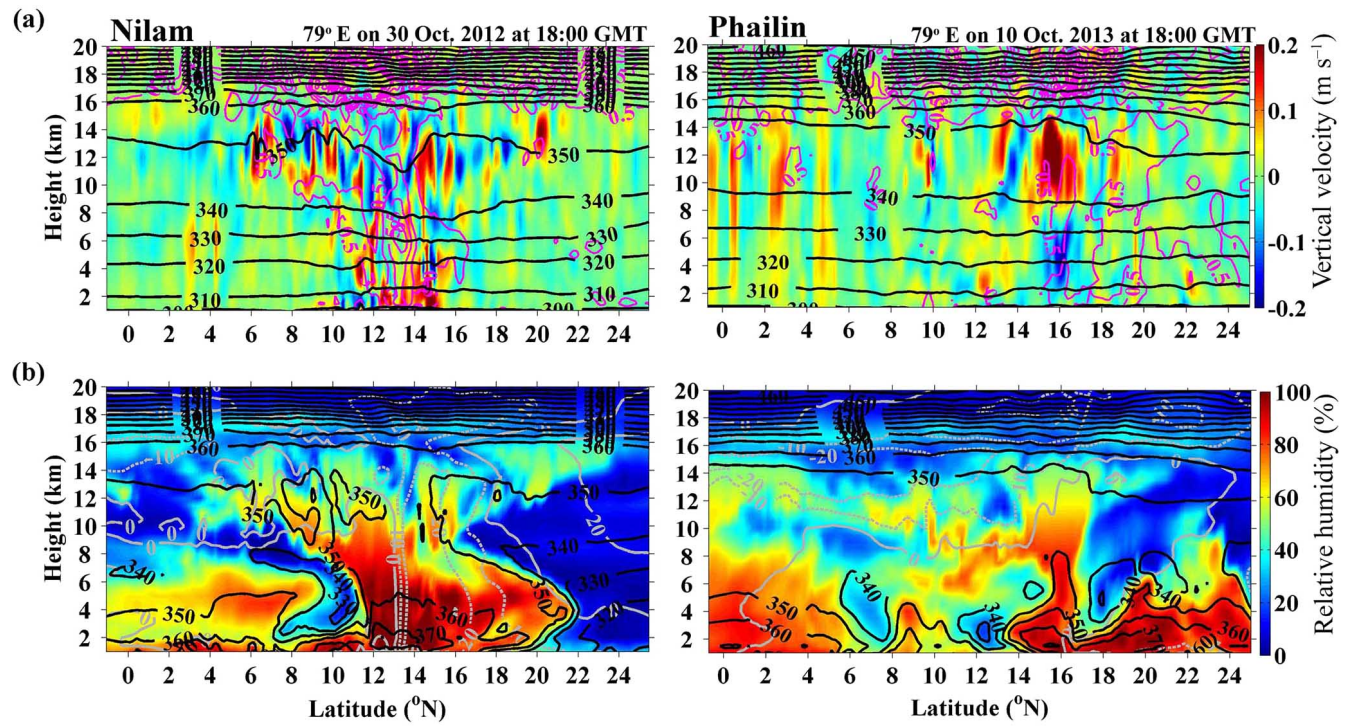

Figure 6. Same as Fig. 5 but at $79^{\circ} \mathrm{E}$ at 18:00 GMT on 30 October 2012 for Nilam (left panels) and 18:00 GMT on 10 October 2013 for Phailin (right panels).

condition indicates the presence of statically stable stratospheric air in the upper and middle troposphere. In addition, strong wind shear is also observed in the UTLS region.

Similarly, Fig. 6 shows the height-latitude cross section of (a) vertical velocity along with potential vorticity (magenta line) and potential temperature (black line) contours, and (b) relative humidity cross section along with equivalent potential temperature (black line) and zonal wind (grey line) at $79^{\circ} \mathrm{E}$ at 18:00 GMT on 30 October 2012 for Nilam (left panels) and 18:00 GMT on 10 October 2013 for Phailin (right panels) using WRF simulations. The vertical velocity profiles show the presence of downdraught (blue) followed by updraught (red) between 8 and $17^{\circ} \mathrm{N}$ in the UTLS region in both cyclone cases. Enhanced potential vorticity of $0.5-1.5 \mathrm{PVU}$ is also observed vertically down from the stratosphere to the lower troposphere, overlapping the down- 

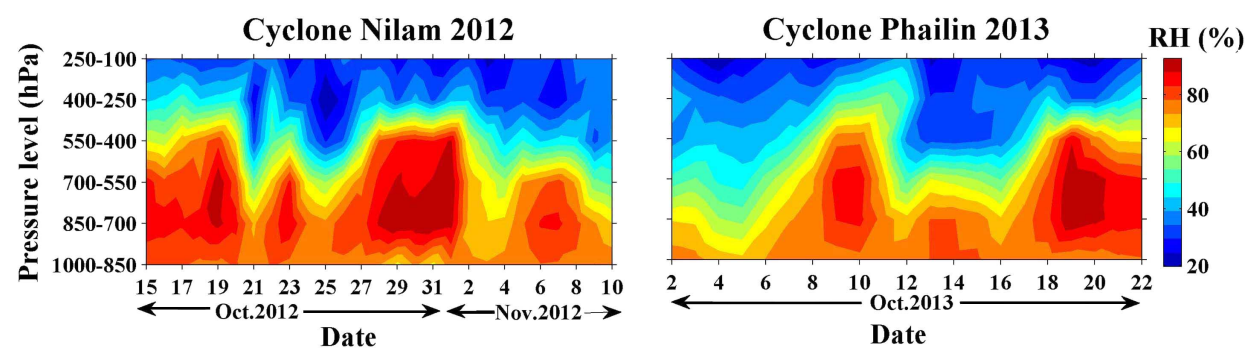

Figure 7. Pressure-time cross section of relative humidity obtained from SAPHIR on board the Megha-Tropiques satellite during the cyclones Nilam (left panel) from 15 October to 10 November 2012 and Phailin (right panel) from 2 to 22 October 2013. The data is averaged over from 4 to $8^{\circ} \mathrm{N}$ and 83 to $88^{\circ} \mathrm{E}$.
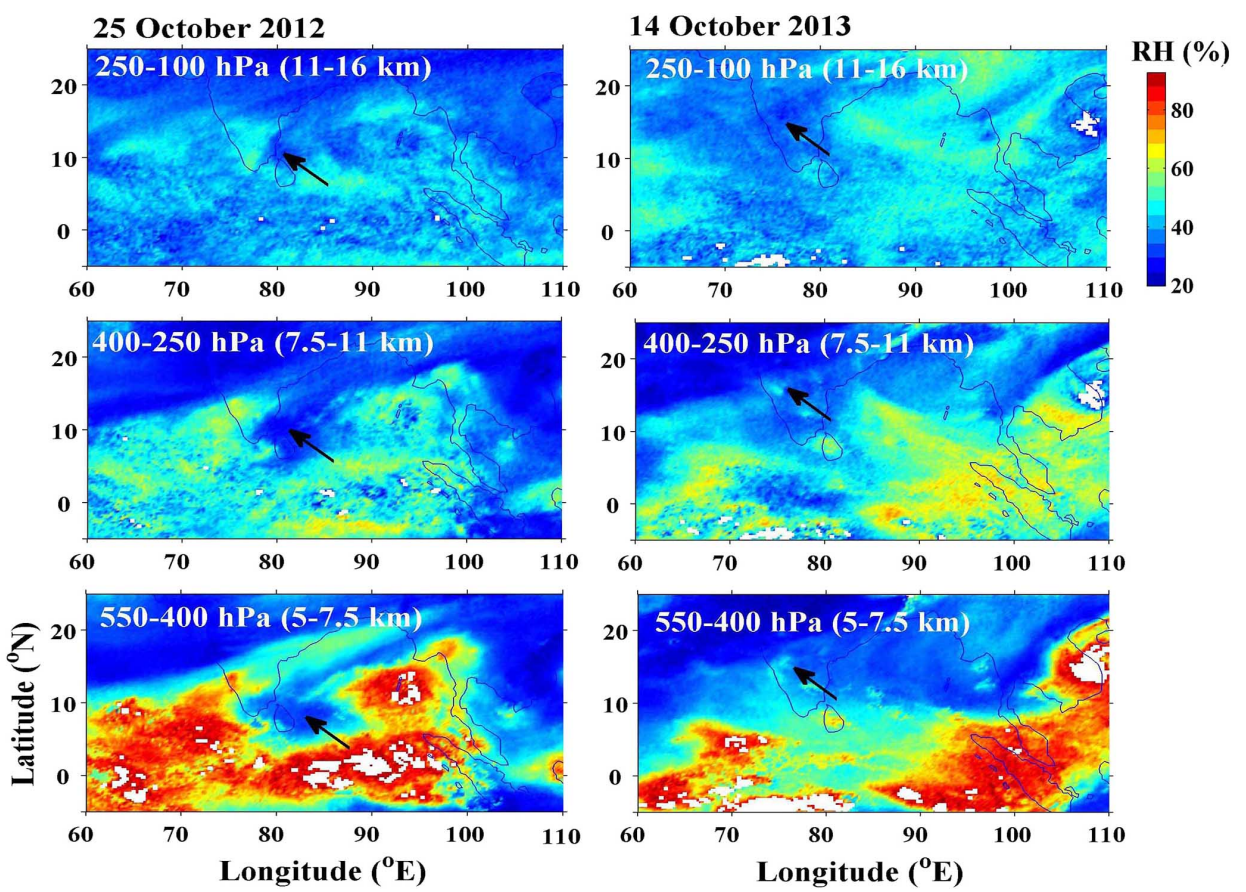

Figure 8. Latitude-longitude distribution of relative humidity derived from SAPHIR on board the Megha-Tropiques at different pressure levels (stamped on each panel) for Nilam (25 October 2012) and Phailin (14 October 2013). The data is averaged for one day, which is about 12-14 passes at different timings, and arrows indicate the presence of dry air.

draught regions. High potential vorticity in the troposphere is also a signature of stratospheric air in the troposphere. It is true that enhanced potential vorticity can also be due to diabatic processes associated with condensational heating but the enhancement is only observed with the presence of downdraught in the UTLS region. The potential temperature contours indicate the presence of reduced stability of the atmosphere at this location and noticed that stable stratospheric air penetrated downward at $12-14^{\circ} \mathrm{N}$ for Nilam and $16-18^{\circ} \mathrm{N}$ for Phailin. Relative humidity profiles indicate the presence of dry air at $\sim 8^{\circ} \mathrm{N}$ which is in the vicinity of ozonesonde observational site. The equivalent potential temperature contours in Fig. $6 \mathrm{~b}$ indicate that from the surface to $10 \mathrm{~km}$, the atmosphere is highly unstable and favourable conditions for the convection took place at $6-12^{\circ} \mathrm{N}$ for Nilam and $12-18^{\circ} \mathrm{N}$ for Phailin. In the same latitude regions from $10 \mathrm{~km}$ to the tropopause level, the vertical motion is suppressed and the atmosphere is found to be statically stable to the unsaturated atmosphere for both Nilam and Phailin. The present condition indicates the presence of statically stable stratospheric air in the upper and middle troposphere in the latitudinal cross section at $79^{\circ} \mathrm{E}$ at 18:00 GMT on 30 October 2012 and 10 October 2013. Numerical simulation reproduced the key features supports the possibility of stratospheric-air intrusion into the troposphere during the passage of tropical cyclone.

To get further insight, relative humidity derived from SAPHIR on board the Megha-Tropiques satellite is used. The relative humidity (daily mean) shown is an average over 1214 passes per day. Figure 7 shows the height-time intensity plot of daily mean relative humidity during the passage of 
the cyclones: Nilam (left panel) and Phailin (right panel). The grid is averaged from 4 to $8^{\circ} \mathrm{N}$ and 83 to $88^{\circ} \mathrm{E}$. Strong dry-air intrusion originated in the lower stratosphere is observed between 23 and 27 October 2012 (Nilam), and 12 and 18 October 2013 (Phailin). In both the cyclones, dry air (low humidity region) reached down to an altitude of $8 \mathrm{~km}$. For the perception of the spatial distribution of relative humidity, a latitude-longitude plot of relative humidity averaged over different pressure levels is shown in Fig. 8. The low value of relative humidity, i.e. the presence of dry air on the same day of enhanced ozone mixing ratio in between 5 and $10 \mathrm{~km}$, indicates the possibility that dry air present in the troposphere is of stratospheric origin. The present observations provide strong evidence for the influence of the tropical cyclone on the air-mass exchange from the stratosphere to the lower troposphere and redistribution of stratospheric ozone. Further trajectory and chemical analyses are required to verify this and to quantify the amount of mass exchange taking place between the stratosphere and the troposphere.

\section{Summary and conclusions}

The important results brought out in the present analysis during the passage of cyclonic storms Nilam (2012) and Phailin (2013) are summarised below:

a. An increase in the upper-tropospheric ozone by 20 $50 \mathrm{ppbv}$ is observed from the climatological mean.

b. The upper-tropospheric ozone propagates downwards to the lower troposphere at a rate of $0.8-1 \mathrm{~km} \mathrm{day}^{-1}$.

c. An increase of about $10 \mathrm{ppbv}$ in the daytime and 10 $15 \mathrm{ppbv}$ in the night-time is noticed in the surface ozone.

d. Significant variation in the cold-point tropopause altitude and temperature associated with tropical cyclones are noticed.

In the present study, the descent of stratospheric air into the troposphere has been deduced indirectly from a combination of ozone and meteorological observations and from modelling. The study clearly reveals that the cyclones play a vital role in changing the atmospheric composition apart from being general weather phenomena.

Acknowledgements. Results reported in this manuscript are from the experimental campaign, TSE-C, conducted under the CAWSES-India Phase-II program, which is fully funded by the Indian Space Research Organisation (ISRO) and Government of India, and the authors sincerely acknowledge the same. The authors would like to thank all the technical and scientific staff of the Space Physics Laboratory (SPL) who participated in this TSE-C campaign. The India Meteorological Department (IMD) is highly acknowledged for providing the climatological ozonesonde data. K. V. Suneeth and S. Aneesh are thankful to ISRO for providing doctoral fellowship during the study period. Authors would like to thank the editor and all the three reviewers for their constructive comments and suggestions which helped in the improvement of the manuscript.

Edited by: P. Haynes

\section{References}

Alexander, G. and Chatterjee, K.: Atmospheric ozone measurements in India, Proc. Indian Natl. Sci. Acad., 46, 234-244, 1980.

Appenzeller, C. and Davies, H. C.: Structure of stratospheric intrusionsinto the troposphere, Nature, 358, 570-572, doi:10.1038/358570a0, 1992.

Baray, J. L., Ancellet, G., Randriambelo, T., and Baldy, S.: Tropical cyclone Marlene and stratosphere-troposphere exchange, J. Geophys. Res., 104, 13953-13970, doi:10.1029/1999JD900028, 1999.

Bourqui, M. S. and Trepanier P. Y.:, Descent of deep stratospheric intrusions during the IONS August 2006 campaign, J. Geophys. Res., 115, D18301, doi:10.1029/2009JD013183, 2010.

Cairo, F., Buontempo, C., MacKenzie, A. R., Schiller, C., Volk, C. M., Adriani, A., Mitev, V., Matthey, R., Di Donfrancesco, G., Oulanovsky, A., Ravegnani, F., Yushkov, V., Snels, M., Cagnazzo, C., and Stefanutti, L.: Morphology of the tropopause layer and lower stratosphere above a tropical cyclone: a case study on cyclone Davina (1999), Atmos. Chem. Phys., 8, 34113426, doi:10.5194/acp-8-3411-2008, 2008.

Das, S. S.: A new perspective on MST radar observations of stratospheric intrusions into troposphere associated with tropical cyclone, Geophys. Res. Lett., 36, L15821, doi:10.1029/2009GL039184, 2009.

Das, S. S., Sijikumar, S., and Uma, K. N.: Further investigation on stratospheric air intrusion into the troposphere during the episode of tropical cyclone: Numerical simulation and MST radar observations, Atmos. Res., 101, 928-937, doi:10.1016/j.atmosres.2011.05.023, 2011.

Davies, T. D. and Schuepbach, E.: Episodes of high ozone concentration at the earth's surface resulting from transport down from the upper troposphere-lower stratosphere: a review and case studies, Atmos. Environ., 28, 53-68, doi:10.1016/13522310(94)90022-1, 1994.

David, L. M. and Nair, P. R.: Diurnal and seasonal variability of surface ozone and NOx at a tropical coastal site: Association with mesoscale and synoptic meteorological conditions, J. Geophys. Res.-Atmos., 116, D10303, doi:10.1029/2010JD015076, 2011.

Deshler, T., Mercer, J. L., Smit, H. G. J., Stubi, R., Levrat, G., Johnson, B. J., Oltmans, S. J., Kivi, R., Thompson, A. M., Witte, J., Davies, J., Schmidlin, F. J., Brothers, G., and Sasaki, T.: Atmospheric comparison of electrochemical cell ozonesondes from different manufacturers, and with different cathode solution strengths: The Balloon Experiment on Standards for Ozone sondes, J. Geophys. Res., 113, D04307, doi:10.1029/2007JD008975, 2008.

Dickerson, R. R., Huffman, G. J., Luke, W. T., Nunnermacker, L. J., Pickering, K. E., Leslie, A. C. D., Lindsey, C. G., Slinn, W. G. N., Kelly, T. J., Daum, P.H., Delany, A. C., Greenberg, J. P., Zimmerman, P. R., Boatman, J. F., Ray, J. D., 
and Stedman, D. H.: Thunderstorms: An important mechanism in the transport of air pollutants, Science, 235, 460-465, doi:10.1126/science.235.4787.460, 1987.

Forster, P. M., Bodeker, G., Schofield, R., Solomon, S., and Thompson, D.: Effect of ozone cooling in the tropical lower stratosphere and upper troposphere, Geophys. Res. Lett., 34, L23813, doi:10.1029/2007GL031994, 2007.

Gettelman, A., de Forster, P. M. F., Fujiwara, M., Fu, Q., Vömel, H., Gohar, L. K., Johanson, C., and Ammerman, M.: Radiation balance of the tropical tropopause layer, J. Geophys. Res., 109, D07103, doi:10.1029/2003JD004190, 2004.

Gohil, B. S., Gairola, R. M., Mathur, A. K., Varma, A. K., Mahesh, C., Gangwar, R. K., and Pal, P. K.: Algorithms for retrieving geophysicalparameters from the MADRAS and SAPHIR sensors of the Megha-Tropiquessatellite: Indian scenario, Q. J. Roy. Meteor. Soc., 139, 954-963, doi:10.1002/qj.2041, 2012.

Han, J. and Pan, H. L.: Revision of convection and vertical diffusionschemes in the NCEP global forecast system, Weather Forecast., 26, 520-533, doi:10.1175/WAF-D-10-05038.1, 2011.

Hence, D. A. and Houze Jr., R. A.: Vertical Structure of Tropical Cyclone Rainbands as Seen by the TRMM, Precipitation Radar. 69, 2644-2661, doi:10.1175/JAS-D-11-0323.1, 2012.

Holton, J. R., Haynes, P. T., and Mclntyre, M. E.: Stratospheretroposphere exchange, Rev. Geophys., 33, 403-439, doi:10.1029/95RG02097, 1995.

Hong, S. Y., Dudhia, J., and Chen, S. H.: A revised approach to ice microphysical processes for the bulk parameterization of clouds and precipitation, Mon. Weather Rev., 132, 103-120, doi:10.1175/1520-0493(2004)132<0103:ARATIM>2.0.CO;2, 2004.

Hong, S. Y., Noh, Y., and Dudhia, J.: A new vertical diffusion package with an explicit treatment of entrainment processes, Mon. Weather Rev., 134, 2318-2341, doi:10.1175/MWR3199.1, 2006.

Houze Jr., R.: Review Clouds in Tropical Cyclones, Mon. Weather Rev., 138, 293-344, doi:10.1175/2009MWR2989.1, 2010.

Jacobson, M. Z.: Control of fossil-fuel particulate black carbon and organic matter, possibly the most effective method of slowing global warming, J. Geophys. Res., 107, 16-22, doi:10.1029/2001JD001376, 2002.

Jiang, Y. C., Zhao, T. L., Liu, J., Xu, X. D., Tan, C. H., Cheng, X. H., Bi, X. Y., Gan, J. B., You, J. F., and Zhao, S. Z.: Why does surface ozone peak before a typhoon landing in southeast China?, Atmos. Chem. Phys., 15, 13331-13338, doi:10.5194/acp-1513331-2015, 2015.

Kerr, J. B., Fast , H., McElroy, C. T., Oltmans, S. J., Lathrop, J. A., Kyro, E., Paukkunen, A., Claude, H., Köhler, U., Sreedharan, C. R., Takao, T., and Tsukagoshi, Y.: The 1991 WMO International Ozonesonde Intercomparison at Vanscoy. Canada, Atmos. Ocean, 32, 685-716, doi:10.1080/07055900.1994.9649518, 1994.

Komhyr, W. D., Barnes, R. A., Brothers, G. B., Lathrop, J. A., and Opperman, D.P.: Electrochemical concentration cell ozonesonde performance evaluation during STOIC 1989, J. Geophys. Res., 100, 9231-9244, doi:10.1029/94JD02175, 1995.

Koteswaram, P.: On the structure of hurricanes in the upper troposphere and lower stratosphere. Mon. Weather Rev., 95, 541-564, doi:10.1175/1520-0493(1967)095<0541:OTSOHI>2.3.CO;2, 1967.
Langford, A. O., Masters, C. D., Proffitt, M. H., Hsie, E.-Y., and Tuck, A. F.: Ozone measurements in a tropopause fold associated with a cut-off low system, Geophys. Res. Lett., 23, 2501-2504, doi:10.1029/96GL02227, 1996.

Leclair De Bellevue, J., Réchou, A., Baray, J. L., Ancellet, G., and Diab, R. D.: Signatures of stratosphere to troposphere transportnear deep convective events in the southern subtropics, J. Geophys. Res., 111, D24107, doi:10.1029/2005JD006947, 2006.

Leclair De Bellevue J., Baray, J. L., Baldy, S., Ancellet, G., Diab, R. D., and Ravetta, F.: Simulations of stratospheric to tropospheric transportduring the tropical cyclone Marlene event, Atmos. Environ., 41, 6510-6526, doi:10.1016/j.atmosenv.2007.04.040, 2007.

Loring Jr., R. O., Fuelberg, H. E., Fishman, J., Watson, M. V., and Browell, E. V.: Influence of a middle-latitude cyclone on tropospheric ozone distributions during a period TRACE A, J. Geophys. Res., 101, 23941-23956, doi:10.1029/95JD03573, 1996.

Mathur, A. K., Gangwar, R. K., Gohil, B. S., Deb, S. K., Kumar, P., Shukla, M. V., Simon, B., and Pal, P. K.: Humidity profile retrieval from SAPHIR on-board the Megha-Tropiques, Current Sci., 104, 1650-1655, 2013.

Mitra, A. P.: Troposphere-stratosphere coupling and exchange at low latitude, Adv. Space Phys., 17, 1189-1197, doi:10.1016/0273-1177(95)00735-W, 1996.

Mlawer, E. J., Taubman, S. J., Brown, P. D., Iacono, M. J., and Clough, S. A.: Radiative transfer for inhomogeneous atmosphere: RRTM, a validated correlated-k model for the long wave, J. Geophys. Res., 102, 16663-16682, doi:10.1029/97JD00237, 1997.

National Research Council: Rethinking the Ozone Problem in Urban and Regional Air Pollution, 1051 Committee on Tropospheric ozone formation and measurement, Natl. Acad. Press, Washington, DC, 1991.

Pallamraju, D., Gurubaran, S., and Venkat Ratnam, M.: A brief overview on the special issue on CAWSES-India Phase II program, J. Atmos. Sol.-Terr. Phys., 121, 141-144, doi:10.1016/j.jastp.2014.10.013, 2014.

Pan, L. L., Homeyer, C. R., Honomichl, S., Ridley, B. A., Weisman, M., Barth, M. C., Hair, J. W., Fenn, M. A., Butler, C., Diskin, G. S., Crawford, J. H., Ryerson, T. B., Pollack, L., Peischl, J., and Huntrieser, H.: Thunderstorms enhance tropospheric ozone by wrapping and shedding stratospheric air, Geophy. Res. Lett., 41, 7785-7790, doi:10.1002/2014g1061921, 2015.

Poulida, O., Dickerson, R. R., and Heymsfield, A.: Stratosphere troposphere exchange in a midlatitude mesoscale convective complex, J. Geophys. Res., 101, 6823-6836, doi:10.1029/95JD03523, 1996.

Raju, G.: Engineering challenges in the Megha-Tropiques, Current Sci., 104, 1662-1670, 2013.

Shapiro, M. A.: The role of turbulent heat flux in the generation of potential vorticity in the vicinity of upper-level jet stream systems, Mon. Weather Rev., 104, 892-906, doi:10.1175/15200493(1976)104<0892:TROTHF>2.0.CO;2, 1976.

Škerlak, B., Sprenger, M., and Wernli, H.: A global climatology of stratosphere-troposphere exchange using the ERA-Interim data set from 1979 to 2011, Atmos. Chem. Phys., 14, 913-937, doi:10.5194/acp-14-913-2014, 2014.

Smirnova, T. G., Brown, J. M., Benjamin, S. G., and Kim, D.: Parameterization of cold season processes in the MAPS 
land-surface scheme, J. Geophys. Res., 105, 4077-4086, doi:10.1029/1999JD901047, 2000.

Sprenger, M. and Wernli, H.: A northern hemispheric climatology of cross-tropopause exchange for the ERA15 time period (19791993), J. Geophys. Res., 108, 8521, doi:10.1029/2002JD002636, 2003.

Sreedharan, C. R.: An Indian electrochemical Ozonesonde, J. Phys. E. Sci. Instrum., 2, 995-997, 1968.

Stenchikov, G., Dickerson, R., Pickering, K., Ellis Jr., W., Doddridge, B., Kondragunta, S., Poulida, O., Scala, J., and Tao, W.-K.: Stratosphere-troposphere exchange in a midlatitude mesoscale convective complex: 2. Numerical simulations, J. Geophys. Res., 101, 6837-6851, doi:10.1029/95JD02468, 1996.

Stohl, A., Spichtinger-Rakowsky, N., Bonasoni,P., Feldmann, H., Memmesheimer, M., Scheel, H. E., Trickl, T., Hübener, S., Ringer, W., and Mandl, M.: The influence of stratospheric intrusions on alpine ozone concentrations, Atmos. Environ., 34, 1323-1354, doi:10.1016/S1352-2310(99)00320-9, 2000.

Stohl, A., Wernli, H., Bourqui, M., Forster, C., James, P., Liniger, M. A., Seibert, P., and Sprenger, M.: A new perspective of stratosphere-troposphere exchange, Bull. Am. Meteorol. Soc., 84, 1565-1573, doi:10.1175/BAMS-84-11-1565, 2003.

Subrahmanyam, K. V. and Kumar, K. K.: MeghaTropiques/SAPHIR measurements of humidity profiles: validation with AIRS and global radiosonde network, Atmos. Meas. Tech. Discuss., 6, 11405-11437, doi:10.5194/amtd-611405-2013, 2013
Sunilkumar, S. V., Babu, A., and Parameswaran, K.: Mean structure of the tropical tropopause and its variability over the Indian longitude sector, Clim. Dynam., 40, 1125-1140, doi:10.1007/s00382-012-1496-8, 2013.

Vaughan, G. and Price, J.: Ozone transport into the troposphere in a cut-off low event, Ozone in the atmosphere, edited by: Bojkov, R. and Fabian, P., A. Deepak Publishing Hampton, USA, 415-418, 1989.

Venkat Ratnam, M., Basha, G., Murthy, B. V. K., and Jayaraman, A.: Relative humidity distribution from SAPHIR experiment on board Megha-Tropiques satellite mission: Comparison with global radiosonde and other satellite and reanalysis data sets, J. Geophys. Res., 118, 9622-9630, doi:10.1002/jgrd.50699, 2013.

Venkat Ratnam, M., Ravindra Babu, S., Das, S. S., Basha, G., Krishnamurthy, B. V., and Venkateswararao, B.: Effect of tropical cyclones on the Stratosphere-Troposphere Exchange observed using satellite observations over north Indian Ocean, Atmos. Chem. Phys. Discuss., doi:10.5194/acp-2015-988, in review, 2016.

Wild, O.: Modelling the global tropospheric ozone budget: exploring the variability in current models, Atmos. Chem. Phys., 7, 2643-2660, doi:10.5194/acp-7-2643-2007, 2007.

Zhan, R. and Wang, Y.:Contribution of tropical cyclones to stratosphere-troposphere exchange over the northwest Pacific: Estimation based on AIRS satellite retrievals and ERA-Interim data, J. Atmos. Res., 117, D12112, doi:10.1029/2012JD017494, 2012 . 